\title{
The influence of the language of new media on the literacy of young people in their school assignments and in leisure
}

\author{
Blaženka Filipan-Žignić, Vladimir Legac \\ University of Zagreb, Croatia \\ Katica Sobo \\ Karlovac University of Applied Sciences, Croatia
}

\begin{abstract}
The authors of this research study try to explore the real literacy among young people of today resulting from the influence of the language of new media (especially Facebook and the mobile phone). The impetus for this study comes from frequent complaints that the language of young people has deteriorated due to the negative impact of the language that young people are using in the new media. The authors have done this through an analysis of the way students write in their school assignments and in writings done in their spare time in the new media with regard to (non) existence of the language of new media (such as abbreviations, emoticons and other iconic signs, capitals, dialecticisms, anglicisms, vulgarisms, etc.). In their analysis, the researchers used a computer programme WordSmith Tools 6.0 (Scott 2006). The authors aimed to find out whether or not students in their private language texts use the language of new media (written language with many elements of spoken language and with many abbreviations) and whether or not the students in their school assignments consistently use the standard language without the elements that they normally use in their own language in the new media. The results have shown that secondary school students do consistently write in the standard language in their school assignments, whereas in their leisure activities they use all the elements of the language of new media.
\end{abstract}

Keywords: Internet, Facebook, mobile phone, young people, language of new media, standard

\section{Introduction}

Today's young people spend a lot of time on the Internet (particularly Facebook or smartphone) surfing and looking for different information or by writing their own texts or messages. They are more than any other group aware of the fact that the language of new media is different and this is reflected in their usage of those media. Crystal (2011) has already pointed to the fact that daily millions of lines of spontaneous written language flow into a network of networks (the Internet) and SMS and it is widely known that they are 
largely produced by young people. Such spontaneous written language also helps to explain the framework presented by Koch and Österreicher (1994). It distinguished between the two interrelated concepts of literacy: the conceptual literacy and the conceptual orality, wherby, to put it in a nutshell, those two concepts take turns in a new transformed kind of language. It means that conceptual literacy (the use of standard language) alternates with conceptual orality (elements of spoken language such as abbreviations, clippings, repetitions, anacoluthon, emoticons, varieties of alloglottic elements, regional dialects, etc.). This new phenomenon itself could be termed everyday written language. Crystal refers to this new phenomenon by using the term netspeak. Unavoidable in any serious research of the language of new media are his books (Crystal 2006, 2011) in which he describes the language of various Internet services, from e-mail and the blog and the chat to the social networks, for whose language he notes that it is characterized by 'writing as well as talking' and adds the interactivity as well. Thus for Crystal netspeak is a kind of linguistic articulation in the above mentioned Internet services or 'a type of language displaying features that are unique to the Internet, and encountered in all of the above situations, arising out of its character as medium which is electronic, global and interactive' (Chrystal 2006: 19f). All these features speak in favour of a new variety of language that is worth of being explored in detail. Therefore, this research study presented in this article will be going in that direction.

\section{Literature review}

With no doubt Crystal was a pioneer in the research of the language of new media, but there exist many other praiseworthy authors from the English-speaking world who have dealt with the language of new media. A small selection of them includes Werry (1996), who emphasizes the fact that in chat participants play with language and create hybrid forms, Herring et al. (2004, 2013) who have been analyzing blogs describing them as being asynchronous like websites or forums and tweets that are more similar to SMS communication, Krishnamurthy et al. (2008) who give something like a sociological view of the communication on Twitter stating that most contributions are sent from the web (60\%), Tagg (2009) who in her doctoral dissertation presents a detailed description of the language of the SMS finding deviations from the norm as well as shortenings and clippings, creativity and play with words, Boyd et al. (2010) who describe conversational aspects in addition to a sociological and IT aspects of the communication on Twitter. The first mentioned above Crystal $(2006,2011)$ is famous for his comprehensive description of the communication in all online services other than Facebook.

Literature in German has also yielded a wide variety of research results dealing with the topic of the language of new media. Mention must be made of Döring (2002), who was the first to describe SMS communication and primarily its abbreviations, clippings and acronyms, Huber (2002) who while describing hypertext wonders whether this means that this prefix indicates something more than a normal text or the text above text, Schlobinski (2005 and in many other works) and Schlobinski and Siever (2005), who describe the language and communication in different online services and point to a number of deviations from the language norm, Schlobinski has even published a dictionary of the language of the SMS with 
an interesting title Von HDL bis DUBIDODO ;-), Storrer (2001) who invented the term typed conversations to describe the chat communication, Tuor (2010) who has described the language of social networks and who has found significant deviations from the norms in the texts from the German, English, Spanish and French corpora, Bieswanger (2007) who has made a contrastive analysis of the strategies of time and space saving in German and English SMS's, Dürscheid et al. (2010), who give detailed information about their project about the literacy of the young Swiss people and linguistic description of the language of new media used by young people and who have concluded that in the students texts written as part of the school assignments there are no negative influences caused by the language of new media. The authors of these books and articles do not only describe the language of the online services, but also the language of the SMS, as young people of today do not go anywhere without their smartphone which they use for texting or going on Facebook to send their messages or for editing their status and similar things. Even the titles of the works often reveal features of the language of new media. It is impossible to avoid being startled by the amazing creativity (which is generally a very common feature of the language of new media) of the titles like Binswanger's 2 abbrevi8 or not 2 abbrevi8... (2007) and of many other titles.

Croatian linguistics has also recently seen an upsurge in research studies dealing with the topics relating to the language of new media (the language of e-mail, Facebook, SMS and all the online services). This can primarily be noted among the following authors: TuđmanVuković (1999), who was among the first to describe the language of Croatian e-mails, and who has concluded that Croatian Internet users take the English language patterns in their emails written in Croatian, Žic-Fuchs and Tuđman-Vuković (2008), who point out that information technology in SMS's influences the Croatian language and its verbal system by causing the 'reassortment' of Croatian past tenses, Pavličević - Franić (2009), who sees SMS messages as a new linguistics of communication in the discourse of new media, PavličevićFranić et al. (2010), who have recognized the influence of the English language (which is frequently used in new media) on the functional grammar of the Croatian language, FilipanŽignić (2012a), who has given a detailed description of all linguistic levels of the language of all the Internet services and who has advocated the inclusion of the language of new media into school syllabus with the aim of raising awareness about the differences of communication in formal and informal situations, Filipan-Žignić et al. (2012b), who have concluded that there are no significant differences in language features in SMS communication in English, German and Croatian, Filipan-Žignić (2013, 2015b), who point to language changes on the Internet and who have described blogs, Vlastelić and Vrbanec (2014), who have explored the influence of the language of new media on the vocabulary of university students, Filipan-Žignić et al. $(2015 \mathrm{a}, \mathrm{c})$, who have concluded that there are no significant differences in the language communication on Facebook in German and in Croatian and who have explored the language corpora of secondary school students with regard to the presence of elements of the language of new media.

Before proceeding to the description of the features of the language of new media as they are seen by the latest research results, and which have served as the basis for postulating hypotheses for this research study of the literacy of young people, the authors of this study would like to mention some important works in the field of corpus linguistics and in the filed 
of the study of students' corpora. That literature was of great help for the authors because this current study dealt with a corpus of student texts in the native (Croatian) and foreign languages (English and German) by using WordSmith 6.0 programme as a tool.

Higly prominent in the above mentined fields of corpus linguists are works by Granger, Granger et al. and Horvath. Granger et al. (2002) and Granger (2013) as well as Horvath $(2001,2002)$ describe in detail the criteria for compiling the corpus of students and they were taken into consideration in the description of the current study. Unfortunately, at present in Croatia there does not exist a corpus of student works in Croatian, nor does it exist of student works in English or German as a first foreign language, although there is an international corpus of students of English, the International Corpus Learner English ICLE (Granger et al. 2002), which contains works from 15 countries and includes Slavic countries like Czech Republic and Bulgaria, but unfortunately no student works from Croatia. It can serve as an impetus that one day in the future this corpus that the authors of this text have compiled for the purpose of this current research study of students texts in English as a foreign language could be included into the above mentioned international corpus called ICLE. The principles for compilation of a corpus of student works in English that have been given and described in detailed by Horvath (2001) could be used as guidelines.

In the above mentioned Croatian corpus of student works (as well as in the Facebook corpus) that the authors of this article had compiled for the purpose of this research study, they investigated the presence of elements of the language of new media. It is, therefore, necessary to describe in detail, what kind of language it is.

\section{Features of the language of new media on Facebook and SMS services}

Detailed analyses (Filipan-Žignić et al. 2012b, Filipan-Žignić and Mošmondor 2015) of the two most widespread services among today's youth (Facebook and SMS) according to the language level indicate that they use many elements of the language of new media in their writing primarily in their free time that are primarily characterized by a deviation from the standard language in many respects.

At the orthographic level of Facebook, Filipan-Žignić and Mošmondor (2015a) have noticed a very popular use of lower case letters joined by the hybrid writing with small and capital letters followed by exclusive use of capitals. They additionally report about the occurrences of omissions of empty spaces between words. Obvious and repeated use of different punctuation marks has also been recorded as quite common. According to FilipanŽignić and Mošmondor, most apparent among them is the use of three dots, slightly less common is the use of exclamation and question marks, followed by the repetition of sounds with the purpose of making the statement more emphatic. The presence of errors caused by these modern media cannot be overseen in chatrooms and the timeline of Facebook.

At the graphostylistic level of Facebook, most common are the expressions of feelings, the so-called emoticons, which can be found in practically every sentence or utterance. They are used as a substitute for a variety of facial expressions and the expressions of feelings. The most common are the initial smiling and crying emoticons ( :-), :D, :-(, ) and heightened 
expressions of laughter :-))))), :DD, but one can also come across the signs like :P or :O and similar ones. Extremely rare are $\wedge \wedge$ emojis (Japanese emoticons) and emoticons that are otherwise unavoidable on the web 9 . The occurrence of logograms and other iconic signs such as a heart, $\bullet \bullet$, stars ${ }^{\star * \star \star \star \star \star}$, \$, etc. must also be mentioned. Logograms often appear with a photo. Links like calls for interaction and other expressions to mark laughter (hehe, hihi, hahahaha...) are also quite common (Filipan-Žignić and Mošmondor 2015a).

At the morphological level one can observe various types of shortenings and abbreviations, although it should be noted that the use of abbreviations is not so frequent on Facebook as is the case in the SMS. These are, according to Filipan-Žignić and Mošmondor (2015a), primarily acronyms of English origin (e.g. BTW, LOL, GL, IMO), but there are also Croatian syllabic abbreviations (e.g. $n m g, d n s, u g l, h r v, o d g$, $f k t$, etc.). Researchers have also noticed a large number of shouts, cries, exclamations and interjections as well as instances where young authors of texts try to imitate sounds, describe what is happening or express emotional condition.

At the syntactic level very visible are frequent ellipses of all kinds (Filipan-Žignić and Mošmondor 2015a). Those two researchers thus point to frequent dropping of auxiliary verbs, the use of aorist and imperfekt rather than perfekt, leaving out the subject, shortening of sentences by using three points at all immaginable locations, telegram style, etc. Incomplete sentences marked by three points is one of the essential features of the language of Facebook. The results of the research of those two researchers have also shown that the use of intertextual elements, phraselogisms as well as collocations and all kinds of rhymes can be quite often.

The analysis of the semantic level has revealed all the possible topics that depend on the age of the users. Thus in older adolescents Filipan-Žignić and Mošmondor (2015a) have mainly found topics about free time, but they have noticed that younger ones are more concerned about school so that the two researchers have come across topics related to teachers, assignments, seminars, etc.., but one can also find that they are also dealing with love, music and free time. Music and a variety of songs are usually most common on timelines although sometimes quotations from literature and wise proverbs can also be found. Less frequent are more serious topics like science. Nonetheless, according to the above mentioned authors, it should be noted that on Facebook timeline the vast majority of the texts are dealing with leisure activities and personal reflections.

The analysis of the lexical level reveals the frequent use of anglicisms. Besides anglicisms some germanisms can also be found. Furthermore, unavoidable are regional dialectal expressions. This is quite logical as all these texts are written in colloquial language. In addition to anglicisms and regional dialectal expression, vulgarisms and blasphemies can also be found (Filipan-Žignić and Mošmondor 2015a).

On Facebook, the same authors have found many hypertext elements. These are primarily hyperlinks, navigation bar with elements (timeline, info, photos, notes, messages, friends, events) comments, advertisements, audio and video recordings, join, like, share, poke and other options.

Due to the number of characters as one of the characteristics of SMS, the situation with that kind of service is somewhat different. 
Thus at the orthographic level, punctuation marks, writing in upper case and in lower case letters, repeated graphemes, writing of words spelt together or separated, as well as the errors attributed to the medium have been investigated (Filipan-Žignić et al. 2012b).

The analysis of punctuation marks that was done by Filipan-Žignić et al. (2012b) has shown that they were adequate in $60.4 \%$ messages, mixed in $25.1 \%$ (meaning that correct and incorrect punctuation marks appeared in the same message) and improper in $14.7 \%$ cases.

Concerning capital and small letters, writing was correct in $33.8 \%$ messages, while $17 \%$ SMS messages used lower case letters only and in $49.2 \%$ mixed writing was present (FilipanŽignić et al. 2012b).

Furthermore, the same authors mention (Filipan-Žignić et al. 2012b) that graphemes were often repeated, words were not separated in some messages as well as that errors attributed to the medium occurred quite often, which made some messages hardly understandable and rather problematic.

Many graphostylistic marks or emoticons (Smilies) were recorded in the collected SMS messages: (e.g. :-), :-(, ;-), :->, >:->, :-P-, :-D, :-| :-/, :-9, :--( :--(, :-<, etc). Smilies in the SMS discourse are used to express things that are in oral communication reserved for particles, interjections, mime and gestures. Smilies can be also looked at as creative impulses expressed by limited abilities of a mobile phone.

Furthermore, SMS message language analysis of Filipan-Žignić et al. (2012b) has revealed that there were no significant deviations at the morphological levels, the only exception being abbreviations. A great number of them were invariably used in the SMS discourse. Acronyms were most often encountered, followed by syllable abbreviations, while complex abbreviations were rather uncommon. The analysis of the origin of foreign abbreviations, has shown that mostly English ones (BTW, CU, CID, EOD, FU, FYI, ILU, JK, UOK, etc.) were frequently used, but Croatian ones (AMR, BMK, PDF, SAJB, LP, etc.) were not uncommon (FilipanŽignić et al. 2012b).

The syntactic level was characterised by medium-dictated syntax, or the usage of ellipses in the collected SMS messages, as was cited by the previously mentioned authors. According to them, the main characteristics of this type of syntax were the omission of the subject, omission of prepositions and auxiliary verbs, as well as the usage of aorist and imperfect tenses instead of the perfect tense and telegraphic style.

The analysis of the semantic level has led the authors to conclude that all the topics from everyday life were represented in the collected messages. Most common aspects of life present in the researched collection of SMS messages were love, family, school, friendship, going out, free time, holidays, birthdays, sports, politics, society in general, etc. This clearly shows that almost any topic can be covered by sending an SMS message.

The most important finding of the lexical analysis of Filipan-Žignić et al. (2012b) has shown that a wide variety of anglicisms were recorded in the collected Croatian messages. When looked at more thoroughly, it can be noted that they are primarily those that are frequently used as stylistic variants in the message texts (for example cool, sorry, ok, happy, etc.). The most frequently encountered examples were in greetings, such as hi, hello, hey, haj, etc.). It is interesting to note that the etymological analysis of the abbreviations used in the 
sample has shown that almost $90 \%$ of those used in the corpus of messages were English in origin (as it was cited by the above mentioned authors).

According to the same above mentioned source, the use of regional dialectal expressions was also quite frequently encountered. When used in Croatian messages, they are often used as a sign of intimacy. Other reasons for their frequent use are speed and imitation of spoken language. Vulgarisms and blasphemies were also recorded in the corpus and they were sometimes from the Croatian language, but much more often used were those of the English origin / $f^{* * *}$ you, shit, etc./ (Filipan-Žignić et al. 2012b).

Comparative analysis of the Facebook and SMS discourse in Croatian, German and English revealed that the language present in the Facebook and SMS messages exhibited no significant differences; on the contrary, noticeable similarities were recorded.

Based on the results of all the studies we mentioned above, both in English and German as well as those from the Croatian linguistics (outcomes do not differ greatly in all three linguistics), it can be concluded that the language of new media has considerably changed if compared to the traditional language at almost all language levels, i.e. from the orthographic level, over graphostylistic, morphological, syntactic, semantic, lexical to the (hyper)textual. Due to the fact that it is impossible to list all the results of the research of the new media, only the most important ones will be mentioned. Thus the individual features of the language of the Internet and in particular of the language of the services like Facebook or Twitter and the language of SMS-texts are emoticons (smiles (-) etc.), abbreviations, graphical-stylistic means (e.g. @; ${ }^{\star * *}$; !!! !!; ????; \$\$\$; \#\#\#; hahaha, etc.), repetitions of the same sounds and letters used to describe various emotional states (e.g. hey !!!!!!!!), usage of capitals, ellipses of the abbreviations, loan-words (primarily anglicisms in the case of other languages) vulgarisms and profanities, regional dialectal expressions, logos, web addresses, links, audio and video recordings, etc.

All this points to the fact that the writing style is not different in different languages, but is immanent to the nature of the services of new media and to that kind of communication regardless of the fact whether Croatian, English or German is used.

Consequently, the authors of this research study try to explore the real literacy among young people of today resulting from the influence of the language of new media (especially Facebook and the mobile phone).

This current research study is a follow-up study to an earlier research of the literacy of young people in Croatia that was also carried out as part of a research project like this one described here in this article. In the earlier research, young people of the same age were only surveyed about their writing practices by means of a questionnaire. Hereinafter, the authors of this paper will describe in detail all the elements of the research study which was a followup study to an earlier questionnaire survey and they will explain the reasons why it was necessary to conduct this new study. 


\section{Study}

The research of the influence of the language of new media on language literacy of the secondary school students in their final year of Croatian elite schools (grammar schools) has been conducted in three different counties since 2014 as part of a research project funded by the biggest Croatian university, the University of Zagreb, and whose leaders and researchers are the authors of this paper. In Croatia, in recent years certain voices have been getting louder with their opinion that the use of the language of modern media has been leading to deterioration of the language literacy of young people because of their massive use by the youth of today. As some linguists share the same opinion, it was thought to be necessary to proceed to field research to determine if this was indeed the case. Pilot research was done with a smaller group of $7^{\text {th }}$ grade primary school students (Filipan-Žignić 2012) that gave rise to a systematic study of a larger number of students. Students from elite Croatian secondary schools (grammar schools) in their final year were selected for the first study. After graduating from secondary school, they continue their education at the best colleges in Croatia and all around the world. The researchers wanted to see whether it was possible to detect and follow some linguistic discrepancies in their school works that are regularly written and evaluated twice a year. It is quite natural that in their leisure time the same students frequently use all the Internet services, and presumably, most of them Facebook messages and chat, and they are very familiar with the characteristics of the language of new media. The guiding principle was that they should indeed be able to distinguish and become aware of the fact that the language of new media belongs only to the world of new media and that at school they will have to use the standard without any deviations and without the use of the elements of the language of new media. The first questionnaire survey was done in 2014 (conceptually, it followed Dürscheid et al. 2010) and it consisted of four sections referring to the information on the languages they learn, information on how they write (i.e. whether they use elements of the language of new media and what they are) in the mother tongue and in foreign language(s) as well as the information on how much time and for what purpose they spend on new media. The results of that research have shown that the surveyed students are familiar with the standard and that they continue to use it in formal situations without any elements of the language of new media and that in the new media they systematically use the distinctive language of new media (Filipan-Žignić et al. 2015c).

This current research study presented in this article was a follow-up study to the above mentioned earlier research of the literacy of young people in Croatia. In the earlier research, young people of the same age were only surveyed about their writing practices by means of a questionnaire. The section of the questionnaire dealing with the use of the elements of new media contained 13 elements of the language of new media: abbreviations and clippings, emoticons, small letter writings, capital letter writings, hybrid (mixed letter) writings, use of repeated punctuation and of other characters, shouts and laughter marks, use of phrases 
without the subject, phrases without auxiliary verbs, use of aorist and imperfect tenses instead of perfekt, regional dialectal expressions, vulgarisms and anglicisms. ${ }^{1}$

It should be noted that this current research focused on abbreviations, emoticons (iconic signs), capital letters, the use of anglicisms in Croatian and in German as a foreign language, dialectisms and vulgarisms. This was done because of the obtained results from the questionnaire survey. It was in those elements that they were very different from what had been previously expected. Regarding the previously mentioned fears present in Croatian society, this research study wanted to examine the real situation by using the WordSmith programme to explore the corpus of collected student works. Following this here presented current study, the authors plan to proceed to a new third research study of the literacy that will focus on the writings of students in their final years of vocational schools. This will enable the authors to cover the whole generation of secondary school graduates. The final stage of the possible project will focus on the writings of the $8^{\text {th }}$ grade primary school students in order to compare the literacy of students at the end of primary with the literacy of students at the end of secondary school.

\subsection{Participants and Corpus}

The sample consisted of fourth grade grammar school students from 3 towns in Croatia (Čakovec, Varaždin and Karlovac). It is the final year of the elite secondary school. Participants in the study were 132 students for mother tongue and 132 for foreign language aged 18 or 19. Data collection was in autumn 2015 for mother tongue and for foreign language (mainly English - 75\%, with some students studying German as their first foreign language $-25 \%$. Every year German is less learned as a first foreign language by secondary school students in Croatia, so it was impossible to collect more students' texts in that language).

The corpus that was used in the research consisted of two kinds of texts written by grammar school students. One of them were texts that students had written in school. The other one were texts that they had written in new media during their leisure activities.

School texts consisted of the so-called zadaćnicas. They are essays that Croatian students write twice a year (at the end of the first and the second term) on a given topic and are part of the final assessment of the mother tongue and the foreign language (English and German) as prescribed by the curriculum. Usually they are compositions that have to follow a default structure with an introduction, a body or plot and a conclusion. They must be written in a formal style with some possible, occasional use of elements of colloquial Croatian, English and German respectively.

In terms of the criteria for corpus compilation prescribed and specified by Granger (2002, 2013) and Horvat $(2001,2002)$, these are authentic text data or writings in varieties of language that are mostly standard Croatian, English and German that had been written in the

One of the features of the Croatian language is that in speech aorist and imperfekt (Latin imperfekt or German Präteritum) are practically not used at all. However, following the recent boom of new media, they are increasingly being used on Facebook and in the SMS. 
context of instruction of the mother tongue and foreign language (EFL, GFL) immediately prior to the collection (in synchronic time). The mother tongue corpus contained 64282 words, the English corpus 29896, and the German corpus 7185.

Texts from students' leisure time activities (mostly Facebook) were written in a variety of the language that is mostly appropriate of the language of new media with many elements of spoken language. They refer to texts in the timeline of Facebook, messages and chat, and had been written in the native and foreign language (English and German) immediately before students voluntarily made them available to the authors of this article. The leisure time activities corpus contained a similar number of words as the school texts corpus (Croatian 63301, English - 29767 and German - 7199).

\subsection{Aim of research}

The aim of the research was primarily to explore the writing of these students in their school assignments and those that they write in their leisure time in new media with regard to the existence and non-existence of the elements of the language of new media (such as abbreviations, emoticons and other iconic signs, capitals, dialecticisms, anglicisms, vulgarisms and profanities, etc.). The aim was also to compare the results obtained through the earlier questionnaire survey and the results obtained from real students' texts by means of the WordSmith 6.0 programme (Scott 2006) primarily with regard to the existence of abbreviations, emoticons (iconic signs), capital letters, anglicisms in mother tongue and German as a foreign language, regional expressions, vulgarisms and profanities.

\subsection{Hypotheses}

The starting hypotheses were the following:

H1: the literacy of the students in the sample does not deteriorate because of the influence of the language used by them to write on the Internet and mobile phones;

$\mathrm{H} 2$ : in the texts written in their leisure time, students write in the language of new media;

H3: in the texts written as their school assignments, students write using the standard language with practically no elements that they normally use in their language used in the new media;

H4: there are no significant differences between the texts written in their native and foreign language with regard to the elements of the new media;

H5: significant differences with regard to the results obtained through the questionnaire survey will be visible in the following elements of the language of new media: abbreviations, emoticons and iconic signs, capital letters, anglicisms, regional dialectal expressions and vulgarisms and profanities. 


\subsection{Design and procedure}

In order to examine the real literacy among young people of today, we examined their modes of writing in their school assignments (both for native and foreign language /English and German/) as well as their writing that they do in their free time in new media with regard to the existence or non-existence of the elements of the language of new media (such as abbreviations, emoticons and iconic signs, use of capital letters, dialecticisms, anglicisms, vulgarisms and profanities, etc.). This current research study, as it has already been stated, has been a follow-up study to an earlier research of the literacy of young people in Croatia in which students of the same age were only surveyed about their writing practices by means of a questionnaire that contained 13 elements of the language of new media. They were abbreviations and clippings, emoticons, small letter writings, capital letter writings, mixed (hybrid) letter writings, use of repeated punctuation, use of other signs, exclamations and laughter signs, phrases without subjects, phrases without auxiliary verbs, use of aorist and imperfekt tenses instead of perfekt, use of regional dialectal expressions and the use of anglicisms. For this study, students' pieces of work were first digitalized (264), and then excerpted into a WordSmith Tools 6.0 application (Scott 2006). The use of the elements of the new media in school texts was explored by means of WordSmith 6.0 programme (the application Wordlist - compare 2 Wordlists was used).

The research focused on abbreviations, emoticons (iconic signs), capital letters, the use of anglicisms in Croatian and in German as a foreign language, dialectisms and vulgarisms because in the earlier questionnaire survey the obtained results were in those elements very different from what had been expected. The lists of anglicisms, regional expressions, abbreviations, vulgarisms, emoticons (iconic signs) and words with capital letters were made and they were then compared with the corpus of students' pieces of work in their mother tongue and in foreign language by means of the wordlist application of the WordSmith Tools 6.0 programme. An additional analysis of the use of the elements of new media was made in private texts that students write in the leisure time (primarily texts written on Facebook). Data processing was made and the differences with respect to the earlier results obtained through a questionnaire survey have been found.

\subsection{The instruments of the research}

The instrument used in this research study was WordSmith 6.0 programme. Two different kinds of wordlists (corpora) were compared:

a) a list based on digitalized students' texts that were excerpted into WordSmith 6.0 programme and made by means of the Wordlist application

b) and a list with anglicisms (okej, sory, mail, lajk, kul, cool, klik, share...), regional dialectal expressions ( $k a j$, zakaj, delas, ve...), abbreviations (poz, dns, lp...), vulgarisms and profanities (jebi ga, peder...), emoticons / iconic signs (:), ;)...), and capital letters 
(COMPUTER, HTmobile...) excerpted into WordSmith and made by means of the Wordlist application. ${ }^{2}$

The two lists were compared by using the Wordlist application of the WordSmith Tools 6.0 programme (wordlist - compare 2 wordlists) i.e. the lists with the corpora of students school works and the private pieces of work in mother tongue and in foreign language were compared with the lists with abbreviations, regional dialectal expressions, emoticons (iconic signs), capital letters, vulgarisms and profanities and anglicism in mother tongue and in German as a foreign language.

\section{Results and Findings}

\subsection{School Text Results}

Students use elements of the language of new media in a high percentage only when using new media in their leisure time while at school the same elements are visible only to a very small extent.

Respondents in our study write almost without using the elements of the language of new media if they write at school for school purposes. On the other hand, in the texts that they write in their free time in the new media, they consistently use the language of new media with almost all its elements. The situation was virtually identical for the mother tongue and for foreign languages (English and German). The following is a graph showing the data of the previous survey, which was the origin of our new research using WordSmith 6.0 program.

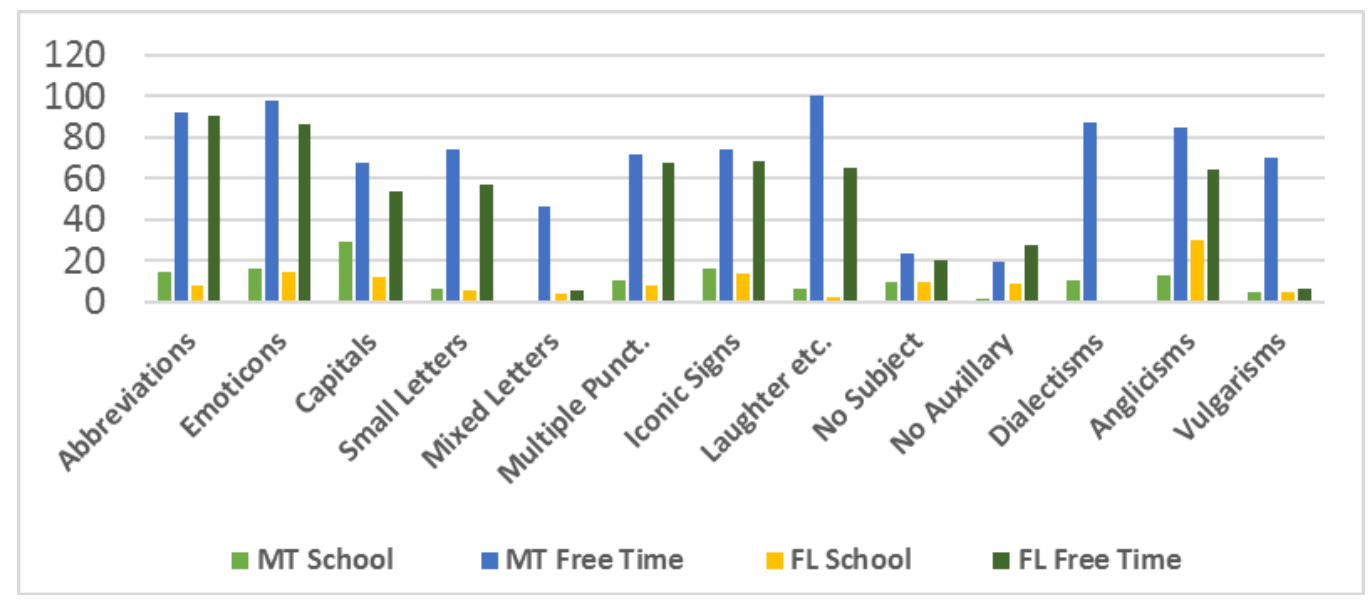

Figure 1: Use of Elements of New Media in Assignments Written at School and for School Purposes and in Texts Written in Leisure Time in New Media (in Mother Tongue and in Foreign Language)

As it was shown in our previous study, participants in our sample generally write in standard both in the mother tongue and in the foreign language when writing at school and for school purposes whereas they use the language of new media with all its characteristic elements when writing in the new media in their leisure time. As the results obtained from the

2 Filipan-Žignić, Legac and Sobo (2015c: 177). 
questionnaire survey had been unexpected in elements such as: abbreviations, emoticons (iconic signs), capitals, dialectisms, vulgarisms, anglicisms (where according to the opinion of the authors the percentages of certain elements of the language of new media in school texts were too high) we had to proceed to the use of WordSmith.

As already stated, lists of anglicisms, regional expressions, abbreviations, vulgarisms, emoticons (iconic signs) were made and they were compared with the corpus of students' pieces of work in their mother tongue and in foreign language by means of the wordlist application of the WordSmith Tools 6.0 programme (see some examples of comparisons in Figs. 2 and 3).

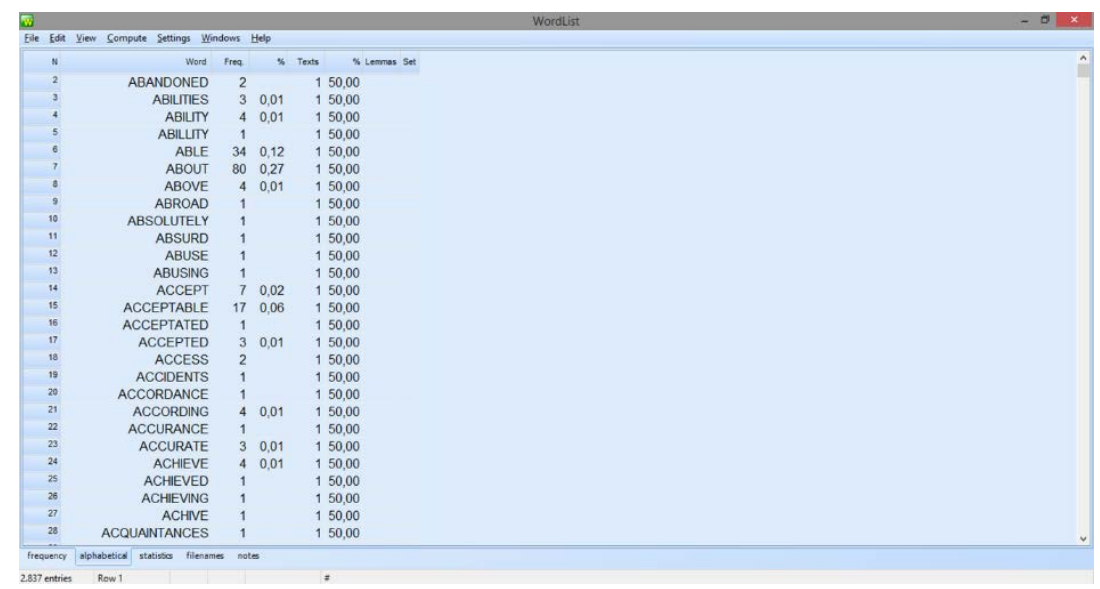

Figure 2: List of the corpus of texts in foreign language (English) compared with abbreviations (shows no match) Results Obtained by WordSmith 6.0

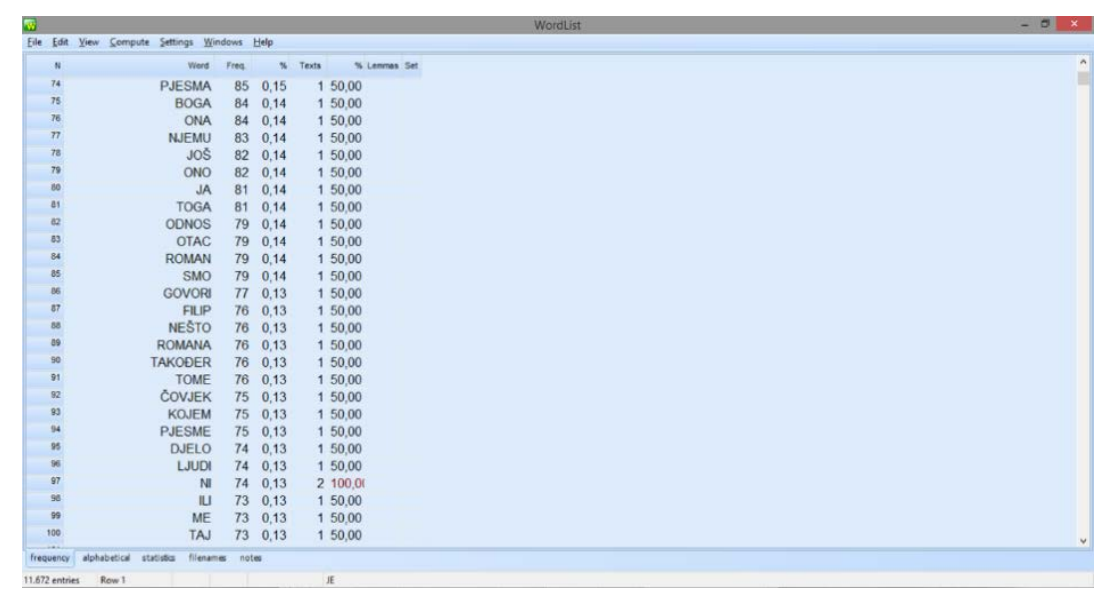

Figure 3: List of the corpus of texts written in mother tongue (Croatian) compared with regional dialectal expressions (indicates that there is match - /indicated in red - ni $=2,100,00 \% /$ ) - Results Obtained by WordSmith 6.0

The same was done for all the lists in mother tongue and English and German as foreign languages. As it would be impossible to present here the whole process of obtaining the final results of the comparisons of the two different lists, only a summary result for all the compared features is given below in Figure 4. 


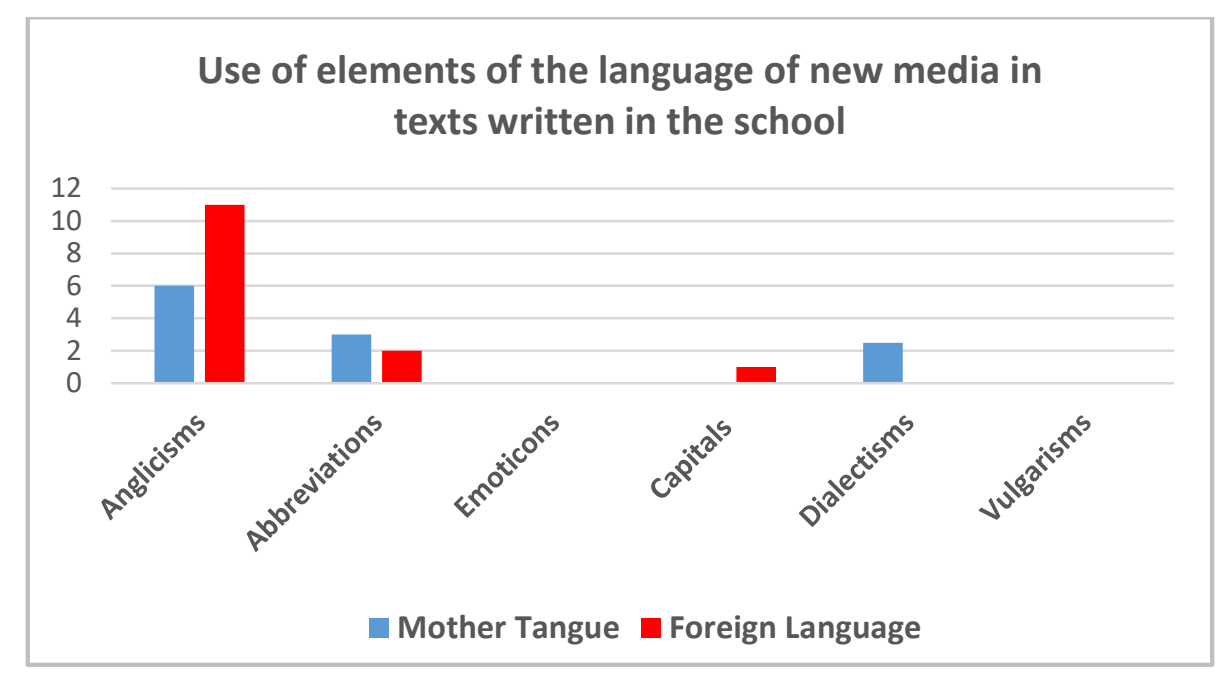

Figure 4: Use of the Elements of the Language of New Media in Texts Written in School in Native and Foreign Language - Summary Results Using WordSmith 6.0

Below is a presentation of the results obtained in the follow-up study (according to particular features) and a comparison with previous studies because the results are similar with minor variations and their separation and detailed presentation elsewhere would not be so evident.

\subsubsection{Anglicisms}

Results of our previous research using the survey showed the following results for the use of anglicisms (questionnaire $=13 \%$ - mother tongue; $29.7 \%$ - foreign language) whereas the research results obtained in our follow-up study using WordSmith 6.0 programs were largely different (Wordsmith $=6 \%$ - mother tongue; $11 \%$ - foreign language). Anglicisms are in fact those that have been in use for quite a while (e.g. sport, hotel, klub, bestseler, diler, etc.). In questionnaires, students had exactly those anglicism in mind, and not those that have only recently come into use and have become part of the language such as: cool, like, click, Facebook. Examples of that kind are represented in small numbers in the texts.

A high percentage of anglicisms (confirmed 11\%) relates to the German language, which is already known for the fact that it comprises a large number of anglicisms especially in the language of young people (star, look, fan, show, story). But even in the students' texts in the German language they are anglicisms that had earlier become part of that language and they are not anglicisms that belong to the new wave and that are widely used by young people on Facebook.

\subsubsection{Abbreviations}

As far as abbreviations are concerned (questionnaire $=14,5 \%$ - mother tongue; 7,6\% foreign language. Wordsmith $=3 \%$ - mother tongue; $2 \%$ - foreign language) we have noticed another misconception: students were thinking of the common abbreviations like itd., etc., $t j$., 
i.e. and not those that have started to be used only recently in modern media like $b t w, t n x, l o l$, and similar.

\subsubsection{Capitals}

Regarding the use of capitals (questionnaire $=29.1 \%$ - mother tongue; $12.2 \%$ - foreign language; Wordsmith $0 \%$ - mother tongue; $1 \%$ - foreign language) it was noticed that students were thinking about the regular use of initial capital letters at the beginning of the sentence or proper names, but the statement in the questionnaire aimed at the use of capitals within words e.g. HTmobile, eBay, eBook, supa亡̌, eDemokracija and similar. Those $1 \%$ that were confirmed by means of the WordSmith programme related to those terms that students were writing about and that appear on the Internet, e.g. titles and names like RoboCop, eBook, Fly onLine and similar.

\subsubsection{Emoticons}

The result obtained through the questionnaire for emoticons and iconic signs remains a mystery (questionnaire $=15.9 \%$ - mother tongue; $14.5 \%$ - foreign language). The analysis of the students texts by means of WordSmith 6.0 programme did not show any evidence for that (WordSmith - 0\%). Theoretically possible is substitution with punctuation, but it seems pretty unlikely. It is more likely that students put some emoticons into the texts for which they do not get any grades. In the follow-up study, the authors used the texts that were marked with grades.

\subsubsection{Vulgarisms}

WordSmith 6.0 has recorded no vulgarisms or profanities (WordSmith $0 \%$ ), whereas in the questionnaire it was approximately $4.6 \%$ (questionnaire $=4.6 \%$ both for mother tongue and for foreign language). The only possible interpretation is that in the questionnaire students were thinking of vulgarism that only by mistake slip into some of the school works for which they do not get any grades, whereas the texts that we explored by using the WordSmith 6.0 programme were only graded texts.

\subsubsection{Dialectisms}

Equally WordSmith 6.0 has shown that students do not use regional dialectal expression as often as they stated in the questionnaire, percentages in actual text usage are lower (questionnaire $=$ approximately $10.7 \%$ for mother tongue, and $0 \%$ for foreign language; WordSmith $=$ approximately $2.5 \%$ for mother tongue). Those dialectal expressions were mainly related to the question word $k a j$ or the negation $n i$ and some wrong usage of the verbal forms like the future form budem radio and similar. 
There are no dialectal expressions in foreign language texts, because students' knowledge is not good enough to enable them to use those expression in the foreign language, whereas their familiarity with such expressions in the mother tongue allows them their use.

\subsection{Private Text Results}

An additional analysis of the use of the elements of new media was made in private texts that students write in their leisure time (primarily texts written on Facebook).

The analysis of the use of elements of the language of new media in texts written on Facebook in mother tongue and in foreign language has shown that there are almost no differences between the results obtained through the questionnaire and the results of the analysis of the contents written by the same age students in their final year at the secondary school. Figure 5 shows the results obtained in our new follow-up study.

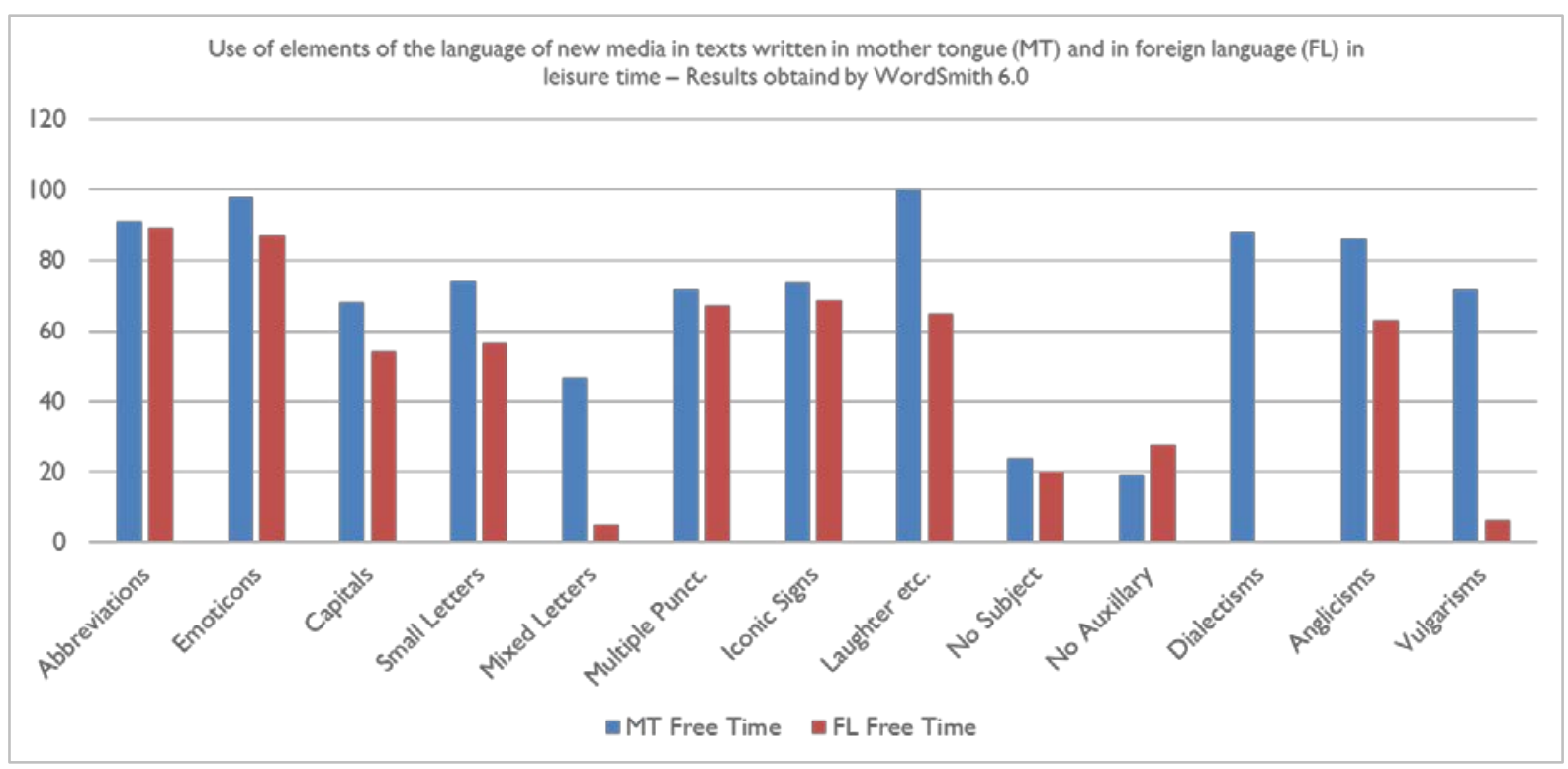

Figure 5: Use of Elements of the Language of New Media in Texts Written in Mother Tongue and in Foreign Language in Leisure Time - Results Obtained by Using WordSmith 6.0 Programme

The results obtained in this study using WordSmith 6.0 software do not differ in any element that we further investigated by means of the same programme (abbreviations, emoticons, capitals, dialectisms, anglicisms, vulgarisms) by more than $1.8 \%$.

\section{Discussion}

Due to the fact that the authors of this paper were not familiar with other papers that could be fully used for comparison, they had to compare the results of this research study with the results of their own earlier research study and a similar study by Dürscheid et al. (2010). The earlier research paper, although it had the same aim, is not fully compatible, because it was an analysis of a questionnaire survey. Most earlier mentioned authors have dealt with the description of the variety of language or the description of the communication used in 
different Internet services (Crystal 2006, 2011, Tagg 2009, Schlobinski et al. 2005, Storrer 2001, Tuor 2010, Filipan-Žignić 2012a, Filipan-Žignić et al. 2012b and many other authors). The information obtained from those sources was very important for the creation of this whole research project. It first helped the authors to draw up their questionnaire for the first survey study. Then, it helped them to form criteria to compile wordlists that were necessary for the analysis of the student corpus by means of the WordSmith 6.0 programme in their follow-up study. To some extent, the results of this research could be compared with the results of the research done by Dürscheid et al. (2010). They carried out a similar questionnaire survey with similar and even some identical items and they analysed students' school assignments and students' leisure time writings in new media. However, there have been some important differences between the two study projects. Dürscheid et al. (2010) did not use WordSmith programme as their tool, but the researchers read students texts. Their target group were younger students aged 14 to 16 years that would be closer to the age of Croatian students in their final grades of primary school. Students in the Croatian project were 18 or 19 years old. Nevertheless, it should be noted that members of the Swiss project have come to very similar results to those obtained by the Croatian project both regarding the results of the leisure time and school assignment texts. In the texts written in their spare time, Swiss students extensively use all the elements of the language of new media (deviations of forms from the standard norms on the phonological level, use of abbreviations, anglicisms, regional dialectal expressions, profanities, emoticons, etc.), whereas in school texts members of the project have almost not noticed any of those elements. They have subsequently concluded that students use the standard as well as that there exist no danger of deterioration of students' language that could be caused by an excessive use of the language of new media on Facebook or other online services.

The previous research of this Croatian team as well as this here presented follow-up research with older students (secondary school leavers) have shown almost identical results both in the Croatian language texts and in the texts in foreign languages (English and German). As for students' writings in their school texts, it has been found that they generally use standard and the use of the elements of new media has not been confirmed. On the other hand, in texts written in their spare time, they indeed use all the elements of the language of new media (including deviations from the norms of the standard language at the phonological, grafostylistic, morphological, syntactic, lexical and hypertextual level). In other words, this means that students very often use multiple punctuation marks as well as emoticons and other symbols, abbreviations and clippings, sentences without auxiliary verbs or without subjects, anglicisms in Croatian and in German, abbreviations, emoticons, vulgarisms and profanities and regional dialectal expressions, but this is only done after school and when new media are used.

\section{Conclusions}

Based on the results of this research study, the authors have come to the following conclusions. There is no evidence to support the widespread opinion that the language of the 
secondary school students in their school works has deteriorated because of the use of language of new media on the Internet and the mobile phone (on Facebook).

It can be concluded that in addition to this hypothesis the results of this research study have confirmed all the other hypotheses. Results have shown that grammar school students generally use the standard in their school texts.

Significant differences with regard to the results obtained through the questionnaire survey were visible in the following elements of the language of new media: abbreviations, emoticons and iconic signs, capital letters, anglicisms, regional dialectal expressions and vulgarisms and profanities.

The differences between the results of the first questionnaire survey study and this follow-up study with the analysis of school texts by means of the WordSmith analysis of contents, i.e. the comparison of wordlists, should be largely interpreted in students' misunderstandings of questions (e.g. btw., tnx and similar were regarded as common abbreviations like itd., etc., tj., i.e., usual capital letters at the beginning of sentences and initial capital letters in proper names were treated in the same way as the usage of capital letters within words) and other similar things for which explanations were given in the chapter on Results and Findings.

Young people extensively use the elements of new media almost only in their private texts that they largely write on Facebook (on the Internet and the mobile phone).

Results of this study have shown no significant differences between the texts in native and foreign language as far as the use of elements of the language of new media. Research studies of the influence of the language of new media on the writing in standard have so far been conducted only with grammar school students.

We can already see a possible objection to this research study by outside observers because grammar school is an elite school and these students belong to the best educated group of students. Consequently, it could be very logical that there are not many elements or few examples of those elements in their school writings. However, the intention of the authors of this paper was to eliminate fears regarding the possibility of the deterioration of the language of that particular group of students and to point to the fact that currently no dangerous tendencies are present as a result of the influence of the frequent use of modern media by grammar school students.

As it has already been earlier mentioned, the authors of this paper are planning to proceed to start a new research study with the population of students characterized by a slightly weaker level of education. They will be students from vocational schools. Only then will it be possible for the authors and the whole Croatian society to present a more authentic picture of the writing mode of the whole generation of young people.

\section{References}

Bieswanger, M. 2007. 2 abbrevi8 or not 2 abbrevi8: A Contrastive Analysis ofdifferent Space- and Time-Saving Strategies in English and German Text Messages. Texas Linguistics Forum 50: 1-12. 
Boyd, D., S. Golder, and L. Gilad. 2010. Tweet, Tweet, Retweet: Conversational Aspects of Retweeting on Twitter. Proceedings of the 43rd Hawaii International Conference on Social Systems. Kauai: University of Hawai'i at Manoa: HICSS 43. http://www.danah.org/papers/TweetTweetRetweet.pdf.

Crystal, D. 2006. Language and the Internet. University Press: Cambridge.

Crystal, D. 2011. Internet Linguistics. London, New York: Rutledge.

Döring, N. 2002. Kurzm. wird gesendet: Abkürzungen und Akronyme in der SMS-Kommunikation. Muttersprache 2: 97-114.

Dürscheid, C., Wagner, F. and S., Brommer. 2010. Wie Jugendliche schreiben. Schreibkompetenz und Neue Medien. Berlin and New York: de Gruyter.

Filipan-Žignić, B. 2012a. Jezik novih medija. Split: Matica hrvatska.

Filipan-Žignić, B, K. Sobo, and D. Velički. 2012b. SMS Communication - Croatian SMS Language Features as Compared with those in German and English speaking Countries. Revija za elementarno izobraževanje 5: 522.

Filipan-Žignić, B. 2013. Jezik moje bake i internet. Čakovec: Matica hrvatska.

Filipan-Žignić, B. and L. Mošmondor. 2015a. Jezična promjena uzrokovana novim medijem internetom. Primjer Facebooka na hrvatskom i njemačkom jeziku. In S.A. Toth (ed.), A Magyar Tudomany napjan elhangzott horvat (es angol) nyelvü elöadasok gyüjtemenye 2013-IG, 27-45. Baja: Eötvös József Főiskolán.

Filipan-Žignić, B. 2015b. Sprache von kroatischen und deutschen Weblogs. In J. Toth (ed.), Language and its Study between Tradition and Innovation, 73-84. Frankfurt am Main, Berlin, Bern, Bruxelles, New York, Oxford and Wien: Peter Lang.

Filipan-Žignić, B., V. Legac, and K. Sobo. 2015c. New Literacy of Young People Caused by the Use of New Media. Procedia-Social and Behavioral Sciences 1, 192C: 179-186.

Granger, S., Dagneaux, E., Meunier, F., and M. Paquot. 2002. International Corpus of Learner English. Version 2. Handbook and CD-ROM. De Louvian: UCL Presses universitaires.

Granger, S. 2013. A Bird's-eye view of learner corpus research. In S. Granger, J. Hung, and S. Petch-Tyson (eds.), Computer Learner Corpora, Second Language Acquisition and Foreign Language Teaching, 3-33; Amsterdam and Philadelphia: Benjamins.

Herring, S., Kouper, I., Scheidt, L.A., and E. Wright. 2004. Women and Children Last, The Discursive Construction of Weblogs. Into the Blogosphere. University of Minnesota. http://blog.lib.umn.edu/blogosphere/women_and_children.html.

Herring, S., Stein, D., and T. Virtanen. 2013. Introduction to the pragmatics of computermediated communication. Berlin and Boston: de Gruyter Mouton.

Horvath, J. 2001. Introductions and Conclusions in advanced EFL Students' Writing: Evidence from the Corpus. Teaching English with Technology 1(5): 3-12.

Horvath, J. 2002. Advanced writing in English as a Foreign Language. A Corpus-Based Study of Processes and Products. Pecs: Lingua Franca Csoport.

Huber, O. 2002. Hyper-Text-Linguistik. TAH: Ein textlinguistisches Analysemodell für Hypertexte. Ph.D. diss., Ludwig-Maximilians-Universität, München. http://edoc.ub.unimuenchen.de/archive/00000921/01/Huber_Oliver.pdf.

Koch, P., and W. Österreicher. 1994. Unterscheidung von medialer und konzeptueller Mündlichkeit bzw. Schriftlichkeit. In G. Hartmut and O. Ludvig (eds.), Schrift und Schriftlichkeit. Writing and Its Use, 587-604. Berlin and New York: de Gruyter.

Krishnamurthy, B., P. Gill, and M. Arlitt. 2008. A few chirps about twitter. Proceedings of the First Workshop on Online Social Networks. WOSP '08. ACM and New York, 19-24. doi:10.1145/1397735.1397741.

Pavličević-Franić, D. 2009. SMS-poruke - nova lingvistika komunikacije u diskursu novih medija. In M. Brdar, M. Omazić, B. Belaj, B. Kuna (eds.), Lingvistika javne komunikacije: Sociokulturni, pragmatički i stilistički aspekti, 231-252. Zagreb, Osijek: HDPL.

Pavličević-Franić, D., T. Gazdić-Alerić, and K. Aladrović Slovaček. 2010. Utjecaj engleskoga jezika na funkcionalnu gramatiku hrvatskoga jezika. In D. Pavličević Franić and A. Bežen (eds,), Društvo i jezik višejezičnost $i$ višekulturalnost, 234-247. Zagreb: UF; ECNSI. 
Schlobinski, P. and T. Siever. 2005. Sprachliche und textuelle Aspekte in Weblogs. Ein internationales Projekt. Networks, 46. Hannover. http://www.mediensprahe.net/networx/networx-46.pdf.

Scott, M. 2006. Oxford WordSmith Tools 6.0. Oxford: Oxford University Press.

Storrer, A. 2001. Getippte Gespräche oder dialogische Texte? Zur kommunikationstheoretischen Einordnung der Chat-Kommunikation. Sprache im Alltag. Beiträge zu neuen Perspektiven in der Linguistik, 439-466.

Tagg, C. 2009. A Corpus Linguistics Study of SMS Text Massaging. Birmingham: The University of Birmingham. Dissertation. Manuscript.

Tuđman-Vuković, N. 1999. Neke odlike jezika interneta - primjer elektroničke pošte. In L. Badurina, N. Ivanetić, B. Pritchard and D. Stolac (eds.), Jezična norma i varijeteti, 797-805. Zagreb, Rijeka: HDPL.

Tuor, N. 2010. Online-Netwerke. Eine kommunikationstheoretische, sozialpsychologische \& soziallinguistische Analyse. Networx 55. http://www.mediensprache.net/networx/networx-55.pdf.

Vlastelić, A., and S. Vrbanec. 2014. Btw, tnx, što me lajkaš! Lol :) Istraživanje utjecaja medija na rječnik hrvatskih studenata. In A. Peti-Stantić, M.M. Stanojević and G. Antunović (eds.), Standardni jezici i sociolekti u 21. stoljeću, 177-194. Zagreb: Srednja Europa: HDPL.

Werry, Ch. 1996. Linguistic and Interactional Features of Internet Relay Chat. In S.C. Herring, (ed.), Computermediated Communication. Linguistic, Social and Cross-cultural Perspectives. New Series 39: 47-63.

Žic-Fuchs, M. and N. Tuđman-Vuković. 2008. Communication technologies and their influence on language: Reshuffling tenses in Croatian SMS text messaging. Jezikoslovlje 91(2): 109-122. 